\title{
Autobiography and Ethical Literary Criticism
}

\author{
FLORENCE KUEK \\ LING TEK SOON
}

\begin{abstract}
Autobiographies are traditionally understood as means of selfredemption or self-validation of the respective autobiographers, but they seem to have become tools of self-assertion in the recent times. The writers of this paper noticed that the underlying patterns in major autobiographies of the respective centuries such as those of Augustine, Rousseau, Virginia Woolf, Han Suyin and other male or female autobiographers commonly evolve around one's ethical choices in response to the vices caused by one's natural will and when facing ethical dilemmas caused by life challenges. This paper examines the abovementioned autobiographies via the Ethical Literary Criticism (ELC). Developed by Professor Nie Zhenzhao since 2004, ELC is one of the most insightful critiques in expounding the relationship of the self with oneself, self with others, and self with the divine or higher moral order in the context of the literary world.
\end{abstract}

Keywords: autobiography; Ethical Literary Criticism; ethical choice; rational will; natural will

\section{Introduction}

After a decade of the revival of ethical literary criticism (ELC) with its unique Chinese slant by Professor Nie Zhenzhao, the adherents of the critical method are gaining in number internationally. As Nie and his colleagues organize an annual conference where hundreds of ELC proponents around the world meet and sharpen their pens, criticism that employs ELC is starting appear in international journals. To name ELC has been featured in the China-based Foreign Literature Studies, the Germany-based Arcadia, and the Taiwanese Universitas: Monthly Review of Philosophy and Culture. The American-based Comparative Literature and Culture has confirmed publishing a special issue on ELC by end of 2015. Even The London-based Times Literary Supplement took notice of the method and practice of ELC in its July 2015 issue. This paper attempts to introduce and engage ELC in the reading of the autobiographies of reputable authors who marked the turns of new epochs in autobiographical writing, namely Augustine, Rousseau, Virginia Woolf and Han Suyin. 


\section{Ethical Literary Criticism and its Key Terms}

The ELC is a literary approach that analyzes, interprets and examines literary work through the study of the ethical elements that are embedded in the structure and meaning of any given literary texts. In 2004, Professor Nie Zhenzhao presented a preliminary proposition for ELC, which took into consideration the ethical environment that had defined the deliberations and actions of characters in a literature, making observations on the ethical lines and knots that were embedded in the storyline. In 2010, the ELC took on a firm grounding when Nie presented carefully defined key terms for the approach. In 2012, the International Association of Ethical Literary Criticism (IAELC) was officially established. According to Professor Jüri Talvet, Vice President of the IAELC, the aim of the IAELC was:

...to initiate a new trend of international literary scholarship that would form a certain counterweight to Western literary studies, which at least since the last quarter of the $20^{\text {th }}$ century have indeed oscillated between two extremes: on the one hand, linguistic-formalistic research (including narratology, cognitivistics, language philosophy applied to literature, etc.) and, on the other hand, sociological approaches (discourses on power relations, postcolonial scholarship, gender studies, etc.). (Talvet 2014: 17-21)

According to Nie, key proponent of the ELC, this method of literary criticism aims at tackling "issues concerning the human essence unanswered in Darwinian evolution” (Nie 2015a: 19). For Nie, Darwin's rationale of natural selection, or the "survival of the fittest" theory, could never piece together a satisfactory explanation about the essence of man. Instead, Nie proposes that ethical selection and ethical choice, which is guided by the human rational mind, will be instrumental in bringing forth the "human" element in man's nature. To the understanding of the writers of this paper, Nie uses ethical selection in contrast with natural selection, to describe the engagement of ethics in the volitional activities of human species. Ethical choice instead is employed regarding man's daily decisions, in which conscious ethical deliberations are involved. For Nie, ethics or ethical exposures is the core of man's written literature. "The value of world literature is not in its power to entertain, but in its function to facilitate the understanding of human life and society in the light of social ethics." (Nie 2012: 9)

Under Nie's leading scholarship, ELC has been given a solid theoretical framework with clear, identifiable key terms such as animal factor, human factor, natural will, rational will, natural selection, ethical selection, ethical choice, ethical 
KUEK, LING

dilemma, ethical identity, ethical environment and ethical reconstruction. The ELC provides an altogether new reading experience of literary texts, especially when one reads literature which carries the post-colonialism, feminist or neo-Marxist labels. ELC, instead of getting political or polarized by those labels, uses lenses that are least divisive when examining the elements of a literature. Also, ELC is extremely revealing when studying the complicated human relationships. Marking literary works as carriers of meaning and ethics, ELC also provides in-depth perspectives regarding the cognition, affection and volition of human beings pertaining to the time and tides in literary texts. This paper seeks to examine major autobiographies across the centuries via ELC, in order to examine ethical relationship between people in that respect.

\section{Autobiography as a Literary Genre}

An autobiography is a self-written account about a person's own life. Different from biographies, which are accounts of other people about a person, autobiographies are the biographer's own account. Based on one's vivid memories of one's life, significant people such as politicians, social advocates and other high impact personalities produce autobiographies to expose their selves, along with their reflections on events and people during their era.

Autobiographical writing as a literary genre is not without dispute. When William Wordsworth first worked on his autobiographical writings in 1805, it was still "a thing unprecedented in literary history that a man should talk so much about himself" (Marcus 1994: 11). But by 1850, when Wordsworth's The Prelude was published, readers were relatively acquainted with autobiography as a literary genre (ibid.). Autobiographies produced over the centuries have altogether served four different functions, or overlapping of some of the functions. First, some wrote autobiographies for the educational or didactic function. Saint Augustine of Hippo (354-430) chronicled Confessions, depicting his spiritual journey in combating stubborn carnal desires so as to shed light on how one's profound relationship with the Creator and the internalization of the Holy Word might be crucial for wise living. The early feminist thinker Elizabeth Cady Stanton wrote Eighty Years and More: Reminiscences, 1815-1897 (1898) with an overriding educational aim, namely to showcase women as the equal counterparts of men, presenting herself as a role model of "an ordinary human being," and not as a wife-housekeeper-mother (Jelinek 1980: 73). Nelson Mandela's Long Walk to Freedom (1994) argued for the logical and natural right of the black majority to rule their own motherland, besides confirming that the safety and rightful presence of the minority ethnic groups could still be preserved under the concept of South Africa for all people. 
Second, autobiographies may serve the confessional function in which one attains salvation or the ultimate meaning of life. St. Augustine's Confessions (written between AD 397-400) started the tradition of confessional literature, aiming at setting right the relationship between man and God, thus achieving the purpose of depicting the salvation of one's soul. The $18^{\text {th }}$-century social philosopher Jean-Jacques Rousseau, at the end of his writing career, wrote Confessions (1789) to relieve himself of his life-long burden of unknown depravities and misdeeds that might "cause one to blush," insisting that he should be at least credited as a good and honest man. The autobiography of Benjamin Franklin, one of the founding fathers of the United States, depicted his rewarding success after overcoming his underprivileged family background.

Third, autobiographies might serve as epistemological means to the understanding of oneself and one's life. Rousseau's Confessions concluded that the influence of female figures during his childhood left an irreversible impact upon his sexual orientation after he had attained adulthood. In $M y$ Several Worlds (1954), the Nobel Prize laureate Pearl S. Buck, who was raised in China, recorded her confusion regarding her social identity, especially during her adolescence when she and her family endured the horrendous fear of being expelled from China by the local Chinese. Using the analogy of a "crippled" tree, the China-born Eurasian Han Suyin tried to sort out her multiple identity and inconsistencies of life.

Finally, autobiographies might be employed by some writers as a selfbranding platform for self-assertion and to gain public attention. Craving the heroism attained by great men and women of the world, Harriet Martineau's Autobiography (1855) branded her Unitarian and political controversial ideas as a well-thought theoretical framework that could potentially counter unfulfilling theologies and social structures. Virginia Woolf's self-depiction as a proud member of the elite Bloomsbury set in her Moment of Beings (published in 1972) may also include her in the self-assertion category.

A literary genre of its own, an autobiography is not history-writing or anthropology proper. Depending on its style and structure, an autobiography can be either a narrative or a poetical work, or all at the same time. Though not entirely without omissions or distortions, autobiographies generally contain truthful accounts of people and events during the lifetime of the autobiographers, thus providing snapshots of a sort of life. As subjective as autobiographies could be, they are worth studying, for they offer insights into the understanding of the question "How shall we live?" (Olney 1972: xi). No man is an island. A person's life leaves an impact on the community. Questions regarding one's past, present and future, the cultures and society where one lives, one's spiritual quests, and so forth, are usually captured in between the lines of 
KUEK, LING

one's autobiography. A perpetual theme of human struggle contributes to the birth of notable autobiographies in literary history, namely, the ethical choice of the main character - the "I" - in life situations where culture, social structure and family tradition are all at play.

\section{Spirit versus the Flesh: Saint Augustine's Confessions}

Written between 397 and 398, Augustine's Confessions is the first "true" and complete autobiography in the Western literary history (Marcus 1994: 2). The thirteen-volume Confessions is comprised of two portions. Books I-IX describe Saint Augustine's own account of his long search for the truth; books X-XIII contain his thoughts upon the truth that he has found, which sound like a catechism that is derived from Genesis 1-3. Pine-Coffin, the avid translator of Augustine's Latin work, understood the division of the two parts in ethical terms. He saw the first portion as "a confession of the writer's sin and error," while the second, "a recognition of God's goodness and judgment" (Augustine 1961: 15). The central point of the Confessions was Augustine's profession of faith in God at the time when cults and heretics had been gaining ground. It has become a classic cherished through ages for the wealth of knowledge in it, namely psychology, philosophy and spirituality, giving insights into "the sons of Adam," namely, mankind.

In his self-portrayal of his wanton sexual misconduct before the age of thirtytwo, Augustine presents his identity vividly as "a sinner" who has offended both God and man. Quoting and interpreting from the Book of Galatians, chapter 5 , verse 17 of the Holy Bible, he depicted one of the clearest pictures of man's natural will warring against man's rational will.

... but I was held fast, not in fetters clamped upon me by another, but by my own will, which had the strength of iron chains... For my [natural] will was perverse and lust had grown from it, and when I gave in to lust habit was born, and when I did not resist the habit it became a necessity... But the new [rational] will which has come to life in me and made me wish to serve you freely and enjoy you, my God... So these two wills within me, one old, one new, one the servant of the flesh, the other of the spirit, were in conflict and between them they tore my soul apart. ${ }^{1}$ (Ibid. 164, emphasise ours.)

\footnotetext{
The word within brackets are our additions.
} 
Augustine's dilemma was clear. His natural will gave in to his lust. An addictive behavioural pattern had been reinforced in him over time, to the extent that he could not overcome his carnally rooted "habits" by his free will. Free will, as discussed extensively by the Protestant theologians such as Martin Luther, Louis Berkhof and others, is a theologically laden term. It signifies the power of one's willing choice regarding one's life - an ability that is granted by God to men and women, for He has not created human beings with a disability of making their own choices for their own life (Grudem 1994: 330). The fact that mankind has the free will in making ethical choices in their life rules out the idea of fatalism. Men and women are therefore held responsible for their morality. If one does not guard one's good conscience when making choices in life, the freedom to exercise one's free will will not yield good results, quite to the contrary. When making ethical choices, one resorts to one's rational will to execute ethical judgment and relevant choices. Augustine knew that he had a natural choice that he disapproved of, and a rational choice that he would like to make: "From my own experience I now understood what I had read [in the Book of Galatians, Chapter 5, verse 17, F.K.\&L.T.S.] - that the impulses of nature and the impulses of the spirit are at war with one another." (Augustine 1961: 164-165)

The persistence of the ethical dilemma of the flesh versus the spirit, and the theme of ethical choice between one's rational will against one's natural will have altogether shaped the framework of this extensive autobiographical work of Augustine: how would one choose when one's fleshly lust is battling with one's clear conscience of one's guilt or shame?

\section{Sensuality versus Sexuality: Jean-Jacques Rousseau's Confessions}

In contrast to Augustine's religious virtuosity of the late Classical era, Rousseau's Confessions that was published posthumously in 1782 sought to reveal the entirety of his embarrassing private life to the public. He had but one purpose: that whoever seeking to condemn his imperfections might see his inherent goodness and honesty instead. Not interested in whatever God's opinion about him in the Last Day might be, Rousseau imagined himself presenting his private life for a fair hearing by other men: "I have displayed myself as I was, as vile and despicable when my behaviour was such, as good, generous, and noble when I was so... So let the numberless legion of my fellow men gather round me, and hear my confessions" (Rousseau 1954: 17). Rousseau thus started the shift of the purpose of confessional literature from the reconciliation of man to God to the recovery of one's peace from shameful guilt. He also made extensive connections between the major childhood events in his life and his sexual orientation during 
KUEK, LING

his adulthood. Due to its subjective, individualistic and sensory character, Rousseau's Confessions had crowned him as the father of Romantic Movement.

Most of Rousseau's encounters with women were intense sexual fantasies without actual sexual consummation. Although sexually desiring his object of "love," he was lacking in self-confidence, thus resorting to masturbation and masochism:

To fall on my knees before a masterful mistress, to obey her commands, to have to beg for her forgiveness, have been to me the most delicate of pleasures; and the more my vivid imagination heated my blood the more like a spell bound lover I looked... So it is that my sensibility, combined with my timidity and my romantic nature, have preserved the purity of my feelings and my morals, by the aid of those same tastes which might, with a little more boldness, have plunged me into the most brutal sensuality. (Ibid.27-28)

Rousseau understood "love" as utter dedication to a woman - even if the woman might be twice his age. During his childhood, he was gratified by physical punishment by his godmother Mlle Lambercier. As he recollected, "I had discovered in the shame and pain of the punishment an admixture of sensuality by the same hand." (Ibid. 25, emphasis ours). Rousseau nursed a lifetime admiration and sensual "love" for his patron, Mme de Warens, whom he referred to as Mamma. When addressing her as such, Rousseau felt it easier to hide his intense feelings for her. "How often have I kissed my bed because she had slept in it; my curtains, all the furniture of my room, since they belonged to her and her fair hand had touched them; even the floor on to which I threw myself, calling to mind how she had walked there!" (Ibid.)

It seems that Rousseau was using the idea of "sensuality" to hide his topic of taboo, namely sex with women. Throughout his life, Rousseau suffered from not being able to satisfy his sexual needs in the conventional way. His natural will yearned for sexual contacts with a woman, but his rational will forbade him to violate the woman whom he desired, especially when she was supposed to be his "mother." To satisfy the whims and fancies of his incest tendencies, he chose to confine himself within the realm of "sensuality," rather than crossing the cultural boundaries or social taboos about forbidden sex.

\section{Being versus Non-being: Virginia Woolf's Moments of Being}

The self as capital or property was rather essential to the emergent bourgeoisie during Rousseau's era, namely the $18^{\text {th }}$ century (Marcus 1994: 16). Autobio- 
graphical writing offered a private space as well as a public platform for individuals to explore their self-knowledge and self-identity. John Locke, for example, suggested that identity existed through time; whereas David Hume held that its existence was uncertain (ibid.). In late $19^{\text {th }}$ and early $20^{\text {th }}$ centuries, the theme of spontaneity in self-disclosure became prevalent in autobiographical writings (ibid. 47). Leslie Stephen said in his 1881 essay "Autobiography" that the true autobiography "is written by one who feels an irresistible longing for confidential expansion; who is forced by his innate constitution to unbosom himself to the public of the kind of matter generally reserved for our closest intimacy." (Ibid. 48). Following that, J. Ashcroft Noble expressed that autobiography should allow readers to discover "the secrets of [their] personality" ( $i b i d$.). During the $20^{\text {th }}$ century, awareness of the difficulty of knowing or grasping the self became the thrust of the new discourse in auto/ biographies. In her essay “The New Biography," Virginia Woolf claimed that the days of Victorian biography that focused on the robustness of past ages were over (ibid. 90). Woolf's contemporary Lytton Strachey was instrumental in playing with real and imaginary portraits to showcase the potential of auto/biographies as an art, rather than of science or history.

Though not intended for publication, Woolf left behind a significant collection of autobiographical writings including "A Sketch of the Past," "22 Hyde Park Gate," "Old Bloomsbury," and "Am I a Snob?" The compilation of these autobiographical materials seemed to match Woolf's view of the self, that a person is but "a random heaping together of fragments of a life." (Schulkini 1976: 12) For her, the individual identity was always in flux. She employed juxtaposition of her present self and her past self in "A Sketch of the Past" to invoke reflection and consciousness of one's momentary being: "That is, to make them (referring to memoirs or biographies) include the present - at least enough of the present to serve as platform to stand upon. It would be interesting to make the two people, I now, I then, come out in contrast." (Ibid. 12 and 75)

Besides the switching between the "I-s" of the different moments, Woolf also employed delicate writing techniques to bring attention to one's moment of being. For instance, in "A Sketch of the Past," she used two interconnected memories, namely a glass dome which blazed in the sunset and the burning grass at the end of Paddington Station as reflectors that awaken one's inner, visionary sight of oneself in the midst of the muffled dull environment (Warner 1984: 13). It was then that Woolf showcased one's moments of being in relation to moments of discovery or revelation. That, would be in contrast to the mundane states of one's "non-being" in one's daily life. Woolf's poetic examination of the complexity and momentariness of one's self-consciousness, led to her emphasis on the possibility of one's deliberate and subjective choice for one's 
KUEK, LING

identity. Writing autobiography in itself, was one of her choices to combat the disappointment and inconsistencies of life. Choosing to write became her coping mechanism to deal with the changes of time and tides. "I feel time racing like a film. I try to stop it. I prod it with my pen. I try to pin it down." (Woolf 1982: 158)

Some may infer that Woolf's childhood experience as a victim of incestuous sexual abuse by her half-brothers laid the basis for her confused sexual quests later. Though happily married to an understanding husband, Woolf succumbed to the appeals of her natural will. She became sexually active with a female Bloomsbury member Vita Sackville-West. A writer-artist guild, Bloomsbury served as Woolf's platform to promote feminism and experience liberal sex. In "Old Bloomsbury," Woolf recalled,

Sex permeated our conversation...We discussed copulation with the same excitement and openness that we had discussed the nature of good... But the fact that they can be mentioned openly leads to the fact that no one minds if they are practiced privately. Thus many customs and beliefs were revised. Indeed the future of Bloomsbury was to prove that many variations can be played on the theme of sex ... (Schulkini 1976: 173-175)

Woolf also flirted and fantasized with her lesbian partner through her novel Orlando (1928). In the novel, the protagonist Orlando - an embodiment of Vita - lived through three centuries, changing from one sex to another, but retaining the same personality. Despite having ample opportunities to exploit total freedom in sexuality even as a married woman, Woolf could not attain the soundness of mind. She lost her will to live after battling in vain with her incurable mental illness. Eventually, she chose to drown herself, leaving behind a letter of apology to her grieving husband. Although endowed with a poetic vision regarding "the being", Woolf had chosen not to be.

\section{World Citizenship versus Racial Bigotry: Han Suyin's The Crippled Tree}

Conformity and normalization would be the expectation of any conventional society of the minorities among them. However, for China-born Eurasian physician and author Dr Han Suyin, genuine acceptance of the sideliners might be the trajectory for the shaping of modern global village. Learning from the history of the two world wars, as well as the civil wars and policy changes in China, Han had always felt upset over the overwhelming famines and poverty - the by-products of warfare - which deeply affected the quality of life of the 
common people. A consultant on China at the World Health Organization (WHO), Han depicted how detrimental were the predicaments caused by human disasters. Unlike natural disasters, human disasters were the worst sufferings of all, as they were caused by the vices or unchecked primitive human desires. Of all Chinese literature types, Han paid special attention to the "wounded literature" that was produced soon after the death of Premier Mao in the 1970s, depicting the tragic experiences of the cadres and intellectuals during the rule of the Gang of Four (Han 1992: 32).

Throughout the $20^{\text {th }}$ century, China experienced radical changes. It was also a time when there was least understanding between the local Chinese and the foreigners. To add to their pain, Han and her siblings experienced discrimination by both the Chinese and the Westerners. Resenting the suffocating environment, her elder brother George Chou developed both superiority and inferiority complexes. Though a half-white, he could not earn as much as his German colleagues at work. Too embarrassed of his half-Chinese identity, George chose to marry a white woman and totally discarded any Chinese identity in the names of his children. Once, he hit a Chinese rickshaw coolie cruelly with his walking stick and broke the shafts of the coolie's rickshaw without any solid reason. Recalling George's aggression against the Chinese coolie, Han threw a tantrum on the street a few days later (Han 1972a: 31). Brutality disturbed the conscience of any clear and rational mind. Rejection by Chinese society at large could not justify George's intention to bully a Chinese individual. After all, there was only one clear explanation for George's villainous behaviour against an innocent other: he had acted out of suppressed frustrations and disturbed natural will.

The emotional scars of Han's family, the Chous, were just too many. Han documented her family saga and her own accounts of modern Chinese history in her six-volume autobiography, namely the Crippled Tree series. The most crippling story of her "crippled" family might be that related to two unnatural deaths in her family, which were direct and/or indirect murders by the local Chinese as well as the Westerners. The first death at the onset of her autobiography was the murder of her family chef by local Chinese bandits. The body was decapitated, with his head hung on the tree at the yard. Following the murder, the villagers offered Han's family no empathy but ridicule. The message to this Eurasian family was clear: Get out of "our" territory. It seems that when a conservative group of people comes together to reinforce their ill-defined group identity, one can expect the worst of human nature to be in the display. Very often, biased group perception coupled with confused group emotions would amount to ethical chaos, leading to grave consequences.

The second death was the death of Han's second brother Gabriel Chou, the angel baby in the eyes of Han's mother. One evening, the seemingly healthy 
KUEK, LING

baby developed a fever all of a sudden. Even though she knew that non-whites would only be treated by the white doctor during daytims at the clinic, Han's Belgium-descent mother decided to take a chance. She tried to seek medical attention for baby Gabriel at the doctor's residence - a medical privilege of other whites then. However, her attempt to save her baby was in vain. The doctor's wife stopped her at the door, "Get out, you and your filthy half-caste brat, get out of my house" (Han 1972b: 304). A mixed-blood baby is a half-caste brat. Life or death of a half-caste did not matter to the arrogant French lady. Due to her unchecked natural will that resented any human being unlike her kind, baby Gabriel was refused a fair chance for medical treatment. The baby died the next morning. During that era, it was a cultural taboo for people of different ethnicity to marry and have children. Babies from inter-racial marriages were not seen as legitimate children, and thus not given the equal right to live as others.

The many trials in Han's life had only strengthened her passion for life. She wanted to thrive more than survive. With her dedicated work in the medical profession, as well as her many opportunities to write and teach internationally, Han emerged as a wounded healer, both in practice and in the formation of public ideas. "I had to do it, to live with myself, to be myself, and to continue growing, where mothers had stopped. I would not be a crippled tree... At least I would greet the tomorrow I had not made, even if it killed me." (Ibid. 18) Indeed, the challenges of the tomorrows could not "kill" this woman who had a staunch belief in fulfilling her dreams to feed the poor and garner the good name for her birth country China during the Cold World era. In fact, all of Han's personal choices in life could be summed up as the deliberate and careful use of her rational will. She did not waste her life as a brainless party animal like other Eurasian girls during her time. Instead, she made calculated moves such as hiring Chinese and German tutors to coach her academically, sitting for entrance examinations to enter the Yanjing University and so forth - all of which were quite unlikely ideas for other preteen Eurasian girls during the era. With her perseverance, Han managed to renegotiate the ethical environment of her world. She became a highly sought-after female medical professional and author.

Han also discarded her perpetual struggle regarding her dual identity, but assumed a new identity with a higher calling, namely, seeing herself as a world citizen seeking for peace and harmony for the increasingly diverse global community. As an emigrant from China, Han's life spoke for many international migrants who found themselves different from others whose passports had never been stamped. In 1982, at the time when she claimed her identity as a world citizen in her book Phoenix Harvest, she was one of the $0.06 \%$ of international migrants from China. Later, the Chinese emigration number tripled at the turn of the twentieth to twenty-first century (Liang and Morooka 2004:150). As 
there was rapid growth of transnational migrants as well as new ideas travelling via the cyberspace since 1980s, traditional perception of one's identity needed re-orientation. The anthropologist Erich Kolig once commented, "In a sense everyone becomes diasporic" (Kolig et. al. 2009: 11). Han's tone in the final chapter of her Phoenix Harvest was altogether reassuring: though a Chinese Eurasian in diaspora, she saw her life as a story of a "completed self" (Han 1985: 313). To a large extent, her effort in securing the world's acceptance of cultural outsiders and individuals with bifurcated background finally paid off.

\section{Ethics as the Core of Literature}

Critics of literature divide themselves over the yardstick of literary criticism, of which aesthetics and virtues are perceived as somewhat mutually exclusive. In his article on "Anglo-American Literature and Ethical Criticism", Professor William Baker pointed out that ethical criticism has currently "gone off the boil in the west," but has been revived in China due to the works of Professor Nie Zhenzhao, Shang Biwu and other ELC proponents. The worries of Western critics regarding ELC includes: (a) moralism, namely its possibility to reduce literature to its moral value only, thus allowing morality to overpower aesthetic; and (b) autonomism, that there is the question whether it would be appropriate to apply moral categories to art, instead of evaluation by aesthetic standards alone (Baker 2015: 87-102).

The introduction of ethical aspects in literary criticism could probably be tied to the "virtue turn" in the philosophical realm at the 1980s when Ernest Sosa released his "The Raft and the Pyramid" and introduced the epistemology of virtue. In the following two decades, moral philosophers like Martha Nussbaum and Richard Rorty, as well as literary critics such as S. L. Goldberg, Wayne C. Booth, David Parker and others have been instrumental in incorporating ethics into the theories and practices of literary criticism.

Since 2004, Nie has steadfastly called for ELC, claiming that "literature is a unique expression of ethic and morality within a certain historical period" and that "moral teaching" is the primary function of literature (Nie and Shang 2015: 7). The authors of this paper welcomes Nie's ELC and takes the position that ELC is a non-aesthetic reading of the text, which does not necessarily deny its aesthetic values, thus providing new possibilities for examining texts. In the critique of autobiographies - a literary genre dedicated to the creative and purposeful records of individual lives, ELC captures the root of human ethical struggles and the reaffirmation of man as an ethical being. For instance, ELC lays out how the differences in Augustine's and Rousseau's ethical reasoning 
KUEK, LING

result in two entirely different orientations, namely, one towards the experiences of man's total contentment in the Creator, the latter towards the humanistic movement of sensibility. In the discourse of gender and sex, ELC points out the consequences of taboo violations as well as unchecked indulgence in human harmful primitive desires, and suggests one to be wise in exercising one's rational will when making life choices. Regarding racial rivalry and exclusivity of the cultural custodians against the minorities, ELC delineates how individuals thrive with their altruistic vision and positive choices while battling their respective persecuting environment. In short, by seeing ethics as the core of literature, ELC offers new possibilities for construing the pathos, ethos and logos of an autobiography.

\section{Conclusion}

The purpose of literary criticism is to discover the $\mathrm{X}$ factor, namely the secret that makes certain literature timeless. The employment of ELC in the selected autobiographies discussed above denotes that ethics is quite likely the core of many life stories. When ethics is concerned, the readers will find a man's rational will wars against his natural will. Also, dilemmas and challenges in life would naturally call for choices that have ethical bearings. Augustine dealt with his fleshly needs via his spiritual awakening. Rousseau justified his embarrassing private life with the euphemism of sensuality. Woolf depended upon external reflectors to signify her struggling existence in the midst of mundanity. Han healed her emotional scars by using her life example to state that irregularity rather conformity might be the way to go forward in the increasingly diverse global village. The use of ELC reveals the ethical selection of each autobiographer in facing the trials of their life. It also shows that individuals who have made rational and wise choices would eventually find themselves loved and respected. As a conclusion, though somewhat limited by its unique theoretical framework and core terms, the use of ELC yields satisfying findings in the critique of autobiographies, especially in pointing a wider readership towards a renewed ethical consciousness in human society.

\section{Florence Kuek}

florencekuek@siswa.um.edu.my

Department of Chinese Studies,

University of Malaya

Jalan Universiti

50603 Kuala Lumpur

MALAYSIA 
Autobiography and Ethical Literary Criticism

\author{
Ling Tek Soon \\ lingteksoon@um.edu.my \\ Institute of Chinese Studies \\ University of Malaya \\ Jalan Universiti \\ 50603 Kuala Lumpur \\ MALAYSIA
}

\title{
Works Cited
}

Augustine. 1961. Saint Augustine: Confessions. Transl. R.S. Pine-Coffin. Harmondsworth: Penguin Books.

Baker, W. 2015. Anglo-American Literature and Ethical Criticism. - Forum for World Literature Studies, March, 87-102.

Grudem, W. 1994. Systematic Theology. Grand Rapids: Zondervan.

Han, Suyin. 1972a. Mortal Flower. London: Panther Books.

Han, Suyin. 1972b. The Crippled Tree. London: Panther Books.

Han, Suyin. 1985. Phoenix Harvest. Chicago: Academy Chicago Pub.

Han Suyin. 1992. Wind in My Sleeves. London: Jonathan Cape.

Jelinek, E. C. 1980. The Paradox and Success of Elizabeth Cady Stanton. - E. C. Jelinek, Women's Autobiography: Essays in Criticism. Bloomington: Indiana University Press, 71-82.

Kolig, E., Vivienne S. M. Angeles, Sam Wong, eds. 2009. Identity in Crossroad Civilisations: Ethnicity, Nationalism and Globalisation in Asia. Amsterdam: Amsterdam University Press.

Liang, Zai, Hideki Morooka. 2004. Recent Trends of Emigration from China: 19822000. - International Migration, Vol. 42 (3), http://www.albany.edu/cimp/imig290. $\operatorname{pdf}(17.09 .2015)$.

Marcus, L. 1994. Auto/biographical Discourses: Theory, Criticism, Practice. Manchester: Manchester University Press.

聂珍钊：《文学伦理学批评及其他一聂珍钊自选集》。武汉: 华中师范大学出 版社, 2012年。 [Nie, Zhenzhao. 2012. Ethical Literature Criticism and Others: Selected Articles of Nie Zhenzhao. Wuhan: Huazhong Normal University.]

Nie, Zhenzhao. 2015a. Ethical Literary Criticism: A New Choice of Literary Criticism. Universitas: Monthly Review of Philosophy and Culture 491, 4, Taipei: Universitas Publisher, 5-19.

Nie, Zhenzhao. 2015b. Towards an Ethical Literary Criticism. - Arcadia, 50 (1), 83-101.

Nie, Zhenzhao, Shang, Biwu. 2015. Ethical Literary Criticism: East and West. - Arcadia, $50(1), 4-8$.

Olney, J. 1972. Metaphors of Self: The Meaning of Autobiography. Princeton University Press. 
KUEK, LING

Rousseau, J.-J. 1954. The Confessions of Jean-Jacques Rousseau. Transl. J. M. Cohen. Harmondsworth: Penguin Books. (Original work published 1789.)

Schulkini, J., ed. 1976. Virginia Woolf, Moments of Being. Sussex: The University Press. Talvet, J. 2014. What Is Ethical Literary Criticism? Some Reflections on the Lady Called Filosofia in Dante Alighieri and the Following. - Interlitteraria, 19/1, 7-21.

Warner, E. D., ed. 1984. Virginia Woolf: A Centenary Perspective. London: Macmillan Press.

Woolf, V. 1982. The Diary of Virginia Woolf. 5 Vols. In A. O. Bell (ed.) London: The Hogarth Press. (Original work published 1972.) 